\title{
Forekomsten av angst- og depresjonssymptomer hos samiske og ikke-samiske elever i videregående skole i Finnmark i 1994 og 2014
}

\author{
Siv Kvernmo ${ }^{1}$ og Ronja Sæterhaug Bye ${ }^{2}$ \\ 1) Institutt for klinisk medisin, Det helsevitenskapelige fakultet, UIT Norges arktiske universitet, 9037 Tromsø \\ 2) Peder Holts gate 43, 9950 Vardø \\ Korrespondanse: Siv Kvernmo, siv.kvernmo@uit.no
}

\section{SAMMENDRAG}

Omtrent $15-20 \%$ av barn og unge i Norge vil i løpet av 3-18 års alderen oppleve symptomer på psykiske vansker og i hovedsak angst og depresjon. Flere internasjonale og nasjonale studier har vist at forekomsten av angst- og depressive symptomer blant ungdom har økt i løpet av de siste tiårene. Formålet med denne studien er å undersøke forekomsten av angst- og depresjonssymptomer blant samiske og ikke-samiske videregående skoleelever i Finnmark i 1994 og 2014 og sammenhengen med sosiodemografiske og psykososiale faktorer.

Data fra 1655 videregående skoleelever fra Finnmark i Ung i Nord-studien fra 1994 ble sammenlignet med data fra 1856 videregående skoleelever fra Ungdata-studien gjennomført i 2014 ved de samme skolene. Det ble benyttet samme mål for angst- og depresjonssymptomer (SCL-12) og for de fleste forklaringsvariabler i de to studiene.

Resultatene viste at det var en høyere forekomst av angst- og depresjonssymptomer i 2014 sammenlignet med 1994 både hos jenter og gutter, mens atferdsvansker avtok i samme periode. Mønsteret av prediktorer i 1994 og 2014 var i hovedsak likt med enkelte variasjoner. Kjønn, forholdet til skole og elevenes selvfølelse viste på begge tidspunkt den sterkeste sammenhengen med angst- og depresjonssymptomer. Det var ingen statistiske forskjeller mellom samiske og ikke-samiske elever i forekomsten av problemer og små forskjeller i mønstre av prediktorer.

Konklusjon: Analyser av forekomsten av psykiske vansker blant ungdom med ulik etnisk bakgrunn er viktig for tilretteleggingen av helsetjenester for disse gruppene. Angst- og depresjonssymptomer blant elever i videregående skole i Finnmark har vist en økning fra 1994 til 2014 hos begge kjønn og på tvers av etniske grupper. En svak selvfølelse og et dårlig forhold til skole var de sterkeste forklaringsvariablene på begge tidspunkt og på tvers av kjønn og etniske grupper. Den økte forekomsten angst- og depresjonsvansker fra 1994 til 2014 samsvarer med andre studier, og illustrerer behovet for både forebyggende tiltak og behandlingstilbud for denne gruppen.

Kvernmo S, Bye RS. The prevalence of anxiety- and depression symptoms in Sami and non-Sami high school students in Finnmark county in 1994 and 2014. Nor J Epidemiol 2019; 28 (1-2): 15-25.

\section{ENGLISH SUMMARY}

As much as $15-20 \%$ of children and adolescents in Norway, aged 3-18 years, are suffering from anxiety, depressive or behavioral problems. Recent studies have shown an increase in the prevalence of emotional problems among adolescents during the last decades. The aim of this study is to examine the prevalence and the sociodemographic and psychosocial predictors of anxiety and depression symptoms in Indigenous Sami and non-Sami adolescents in 1994 to 2014.

Data from 1655 high school students in the Young in North (Ung i Nord) study from 1994 was compared to data from 1856 high school students in Ungdata, conducted in 2014 in the same area. Similar and comparable measures were applied in the two studies with SCL-12 as the main measure. The results showed an increase in the prevalence of depression and anxiety symptoms from 1994 compared to 2014, but a decrease in behavioral problems. At both years females reported more problems. No significant ethnic differences occurred in rates of problems between indigenous Sami and non-Sami adolescents at any time point. Across gender and ethnic groups, self-esteem and the students' relationship to the school were the two strongest predictors.

Conclusion: This study confirmed findings from other studies of an increase of rates of anxiety and depression symptoms in older adolescents over the last decades, but also in types of significant predictors. Our findings entail a future need for prevention and treatment offers to adolescents suffering from anxiety and depression problems.

This is an open access article distributed under the Creative Commons Attribution Licence, which permits unrestricted use, distribution, and reproduction in any medium, provided the original work is properly cited. 


\section{INTRODUKSJON}

Befolkningsstudier av psykiske vansker hos barn og unge er viktig for forebygging, men også for planleggingen og tilretteleggingen av gode behandlingstilbud. Flere studier har vist at forekomsten av psykososiale vansker hos ungdom har økt siden 1950-tallet og fram til i dag (1-4). Samtidig har det vært reist kritikk mot disse funnene. Blant annet inkluderer argumentene at det er benyttet ulike mål på psykiske vansker, at de diagnostiske kriteriene har endret seg i denne perioden og at rapporteringspraksis er endret over tid $(1,5)$. Norske studier har også vist en økning i angst- og depresjonssymptomer fra 1990-tallet til 2000-tallet (6). Det finnes ingen studier av endringer i forekomsten av psykiske problem hos samisk og nord-norsk ungdom over en lengere periode. I denne studien har vi sammenlignet forekomsten av angst- og depresjonssymptomer i 1994 og 2014 hos samiske og ikke-samiske videregående skoleelever i de samme områdene i Finnmark ved bruk av de samme måleinstrumenter for psykisk helse. Vi har også undersøkt sosiodemografiske og psykososiale forhold som påvirket forekomsten av symptomene ved de to måletidspunktene.

Angst og depresjon er de hyppigste psykiske lidelser hos barn og ungdom $(5,7,8)$. Disse lidelsene medfører betydelige samfunnsmessige kostnader knyttet til behandling, men også store belastninger og kostnader for individet og familien på grunn av redusert funksjon i forhold til skole, familie, venner, og senere arbeidsliv. Livstidsprevalensen av depresjon blant barn og unge varierer både internasjonalt og nasjonalt. Internasjonale studier angir at 3-6\% av alle barn, fra småbarnsalder og gjennom skolealder, har symptomer som oppfyller kriteriene for en depresjonsdiagnose, mens befolkningsstudier viser en forekomst på 9-12\% for depresjons- og/eller angstsymptomer som er så alvorlige at disse påvirker barnets eller ungdommens daglige funksjon negativt (9-12).

Ungdata-undersøkelsene har påvist at periodeprevalensen av moderate til alvorlige angst- og depresjonssymptomer (siste uke) hos mannlige 10. klassinger i Norge har ligget stabilt rundt 6\% i tidsrommet 20112016 (13). For jenter har tilsvarende forekomst økt fra ca. $16 \%$ i 2011 til $20 \%$ i 2016 . En undersøkelse av samiske og ikke-samiske 10.klassinger i Nord-Norge i tidsrommet 2002-2005 viste en periodeprevalens (siste uke) på ca. 19\% ved bruk av HSCL-10 og den anbefalte cut-off verdi på 1,85 (14). Jenter hadde betydelig mer problemer enn gutter (ca. $31 \%$ versus 7,6\%).

Videregående skoleelever i Nord-Norge har vist seg å ha samme eller lavere forekomst av moderate til alvorlige angst- og depresjonssymptomer som ungdom $\mathrm{i}$ andre deler av landet (15). Sund og medarbeidere (16) fant i 2011 en livstidsprevalens for depresjonssymptomer på $23 \%$ og en punktprevalens for alvorlig depresjon på 2,6\% hos ungdomsskoleelever i MidtNorge. De norske undersøkelsene har benyttet ulike mål på angst- og depresjonssymptomer og også til dels ulike type prevalenser (livstid versus siste uke/to siste uker) noe som kan forklare de ulike funnene.

Flere undersøkelser tyder på at depresjon opptrer ved yngre aldre nå enn før og er relatert til avvikende familieforhold (17). Kartleggingen av risikofaktorer i tidlig barndom har derfor fått større oppmerksomhet de siste årene. Hos unge i likhet med voksne er det funnet en sterk sammenheng mellom angstlidelser og alvorlig depresjon (17). Alvorlig depresjon i ungdomsalder kan også være forløper for angstlidelser hos voksne (18). Ungdom med symptomer på angst og depresjon har ofte lavere psykososial fungering, mer opplevd stress og mindre sosial støtte enn ungdommer uten disse symptomene (17). Det er også påvist en nær sammenheng mellom angst- og depresjonssymptomer og bruk av alkohol eller andre rusmidler hos ungdom (19).

Et godt selvbilde og god selvfølelse beskytter mot angst og depresjon (20,21). Gutter og eldre ungdommer er rapportert å ha et bedre selvbilde enn jenter og yngre ungdom (20). Faktorer som samvær med og sosial støtte fra familie og venner og en oppvekst med begge foreldre virker også beskyttende (19).

Samisk ungdom har på tross av sin minoritetsposisjon nasjonalt sett ikke hatt en høyere forekomst enn ikke-samiske jevnaldrende når det gjelder psykiske vansker inkludert angst- og depresjonsproblemer. Angst og depresjonssymptomer hos samisk og ikkesamisk ungdom har vist ulike mønstre av risiko- og beskyttelsesfaktorer. Funn fra Ungdomshelseundersøkelsen i Nord-Norge viste at sosioøkonomiske forhold i mindre grad påvirket samisk ungdoms emosjonelle problem enn for ikke-samiske. Familiekonflikter var generelt en risiko for utviklingen av angst og depresjonssymptomer med unntak av for samiske jenter, mens samiske gutters symptomer ble negativt påvirket av en svakere tilknytning til familien. Mestringsevne og kulturelle faktorer som samisk språkkompetanse og deltakelse i kulturelle aktiviteter har også vist en beskyttende effekt på samiske ungdommers angst- og depresjonssymptomer (22-24). Angst- og depresjonssymptomer har vært påvirket av den kulturelle konteksten ungdommene vokste opp i. Ungdom som levde i minoritetsposisjoner som norsk ungdom i samiskdominerte områder og samisk ungdom i norskdominerte områder, rapporterte flest problemer $(25,26)$. Dette kan skyldes mer diskriminering og mindre aksept for å være kulturelt forskjellig.

Samtidig med en økning av angst og depresjonssymptomer hos ungdom, har atferdsvansker og bruk av rusmidler minket (13). Mojtabai og medarbeidere (27) fant $\mathrm{i}$ en amerikansk studie at prevalensen av depresjonssymptomer økte fra 2005 til 2014 også etter å ha kontrollert for bruk av rusmidler.

I denne studien ønsket vi å undersøke om forekomsten av angst- og depresjonssymptomer viser samme tendens blant samisk som ikke-samisk ungdom i 1994 som i 2014 og om betydningen av sosioøkonomiske og psykososiale faktorer var de samme i 1994 som i 2014. 
I et samfunns- og helsetjenesteperspektiv vil det være av betydning å kartlegge både samiske og ikkesamiske ungdommers symptombilde og relaterte forklaringsvariabler for å kunne tilpasse og dimensjonere behandlings- og forebyggende tiltak for samiske så vel som ikke-samiske ungdommer både kulturelt og samfunnsøkonomisk.

\section{MATERIALE OG METODE}

\section{Prosedyre}

Studien har benyttet data fra to spørreskjemaundersøkelser blant skolelever ved videregående skoler i Finnmark; Ung i Nord i 1994 og Ungdata i 2014. Undersøkelsene ble utført i skoletiden. Ung i Nord ble gjennomført på papir, mens Ungdata ble utført elektronisk ved at elevene logget seg inn med et unikt brukernavn via nettsiden www.ungdata.no. Ved gjennomføringen av undersøkelsene var en lærer til stede i klasserommet. Undersøkelsene er beskrevet i tidligere publikasjoner (28-30).

\section{Ung $i$ Nord}

Undersøkelsen dekker en rekke tema i ungdommers liv som personlig utvikling, sosiale nettverk, fritid, utdanning, arbeid og skole, psykisk helse, rusbruk, etnisitet, etnisk identitet, seksualitet, pubertetsmodning og kulturell tilpasning. Ung i Nord var den første større epidemiologiske undersøkelsen av nord-norsk ungdoms helse og livssituasjon og omfattet 21 videregående skoler i Nord-Norge (26). Spørreskjemaene var på samisk og norsk. Alle videregående skoler i Finnmark var inkludert unntatt en mindre skole som i 1994 hadde hovedsakelig voksne elever. For å unngå at elevene påvirket hverandres svar ble undersøkelsen gjennomført samtidig for alle skolens elever. Hver elev samtykket skriftlig før undersøkelsen. Undersøkelsen var godkjent av Regional komité for medisinsk og helsefaglig forskningsetikk (REK Nord) i 1993, av Finnmark fylkeskommune og de lokale videregående skolene. Undersøkelsen var finansiert av UiT Norges arktiske universitet.

\section{Ungdata}

Datamaterialet er basert på en Ungdata-undersøkelse, gjennomført i Finnmark i 2014 av NOVA i samarbeid med de regionale kompetansesentrene for rusfeltet (KoRus) (28). Ungdata er en selvrapportert spørreskjemaundersøkelse tilpasset og utført av elever i ungdomsskolen eller videregående skole. Hovedtemaene for Ungdata er ulike sider ved ungdommenes livsstil og livssituasjon, fritid, vennskap, sosialt nettverk, seksualitet, kulturelle verdier, politikk, psykisk helse, rusmidler og antisosial atferd. Ungdataundersøkelsen i Finnmark for videregående skole har også spørsmål om samisk tilhørighet basert på språkkompetanse hos enten eleven, foreldrene eller besteforeldrene. Da undersøkelsen ikke er regnet som helseforskning, var ikke godkjenning fra REK nødvendig. Undersøkelsen er godkjent av Norsk samfunnsvitenskapelig datatjeneste (NSD) og har prosjektnummer 37095. NOVA er ikke ansvarlig for virksomhetens (UiTs) analyser eller fortolkninger av resultatene.

\section{Utvalg}

I Ung i Nord i 1994 deltok 1655 elever hvorav 818 $(49,4 \%)$ gutter og $837(50,6 \%)$ jenter. Fordelingen på klassetrinnene var $749(45,4 \%)$ elever fra videregående trinn 1, $518(31,4 \%)$ elever fra trinn 2, og 383 $(23,2 \%)$ elever fra trinn 3 . Den etniske fordelingen var $363(21,9 \%)$ elever med samisk bakgrunn og 1292 $(78,1 \%)$ elever med annen bakgrunn (Tabell 1). Svarprosenten for Ung i Nord for Finnmark var 90\% (11).

I Ungdata-undersøkelsen i 2014 var det 1819 elever som deltok hvorav 915 (50,3\%) gutter og 904 (49,7\%) jenter. Fordelingen på klassetrinn var $821(45,2 \%)$ elever fra videregående trinn 1, 694 (38,2\%) elever fra trinn 2 og $302(16,6 \%)$ elever fra trinn 3. Den etniske fordelingen var $184(10 \%)$ elever med samisk bakgrunn og 1652 (90\%) elever med annen bakgrunn (Tabell 1). Svarprosenten for Ungdata for Finnmark var $67 \%$.

\section{Instrumenter}

Det er benyttet måleinstrumenter som i all hovedsak finnes både i Ung i Nord og Ungdata. I de tilfeller hvor man har ulike mål på et fenomen, er verdiene rekodet. Dette er beskrevet under de måleinstrumenter hvor dette forekommer. Tabell 2 viser spørsmålenes ordlyd, range og svaralternativer.

\section{Angst- og depresjonssymptomer}

Disse ble målt med tolv spørsmål fra to velbrukte skalaer for angst- og depresjonssymptomer, Hopkins Symptom Checklist (SCL) (31) og Depressive Mood Inventory (DMI) som er utviklet fra SCL (32). Dette kartleggingsverktøyet er benyttet i Ungdata og Ung i Norge-undersøkelsene (6). Ni av spørsmålene har vært benyttet i blant annet Ungdomsundersøkelsene i NordNorge hvor de har vist god validitet og reliabilitet, også i studier av voksne og unge samer $(14,29,33,34)$. Tabell 2 viser en oversikt over spørsmålene for hver skala, range og svaralternativer som er benyttet.

Studier fra Ung i Norge har benyttet ulike verdier som cut-off for depresjon, men hovedsakelig gjennomsnittsverdiene 3 eller $4(6,28,35)$. Valideringsstudier av Hopkins Symptom Check list-10 (SCL-10) har funnet at instrumentet er godt egnet til å oppdage depresjon hos ungdom. Mens Haavet og medarbeidere (36) fant at en cut-off på 1,6 (gjennomsnittsverdi for 14-16 åringer) diskriminerte godt for depresjon hos ungdom i allmennpraksis, fant Strand og medarbeidere (37) en tilsvarende cut-off på 1,85 blant eldre ungdom og voksne som egnet til å fange opp deprimerte individer.

I denne studien utgjør 6 av spørsmålene en depresjonsskala (SCL-depresjon) og 6 av spørsmålene en angstskala (SCL-angst). I tillegg er det en samleskala for samtlige angst- og depresjonsspørsmål (SCL-total). Det er beregnet en gjennomsnittsverdi for hver skala ved å summere verdiene for hvert spørsmål dividert med antall spørsmål. Da våre skalaer ikke tilsvarer den 
Tabell 1. Beskrivelse av utvalgene ved måletidspunktene 1994 og 2014 fordelt på etnisk gruppe.

\begin{tabular}{|c|c|c|c|c|c|c|c|c|c|c|c|}
\hline \multirow[b]{3}{*}{ Variabler } & \multicolumn{5}{|c|}{ Samisk } & \multicolumn{5}{|c|}{ Ikke-samisk } & \multirow{3}{*}{$\begin{array}{c}\text { Totalt utvalg } \\
\text { Effekt av år } \\
\mathbf{X}^{\mathbf{2}} \\
\end{array}$} \\
\hline & \multicolumn{2}{|c|}{1994} & \multicolumn{2}{|c|}{2014} & \multirow{2}{*}{$\begin{array}{c}\text { Effekt av år } \\
\mathbf{X}^{2}\end{array}$} & \multicolumn{2}{|c|}{1994} & \multicolumn{2}{|c|}{2014} & \multirow{2}{*}{$\begin{array}{c}\text { Effekt av år } \\
\mathbf{X}^{2}\end{array}$} & \\
\hline & $N$ & $\%$ & $N$ & $\%$ & & $N$ & $\%$ & $\mathbf{N}$ & $\%$ & & \\
\hline Kjønn & & & & & $.36^{n s}$ & & & & & $.41^{\mathrm{ns}}$ & $.27^{\mathrm{ns}}$ \\
\hline Jenter & 209 & 57.6 & 101 & 54.9 & & 628 & 48.6 & 803 & 49.1 & & \\
\hline Gutter & 154 & 42.4 & 83 & 45.1 & & 664 & 51.4 & 832 & 50.9 & & \\
\hline Klassetrinn & & & & & $3.14^{\mathrm{ns}}$ & & & & & $23.71^{* * *}$ & $30.46^{* * *}$ \\
\hline 1. vgs. & 159 & 44.4 & 78 & 42.6 & & 590 & 45.8 & 743 & 45.5 & & \\
\hline 2. vgs. & 108 & 29.9 & 67 & 36.6 & & 410 & 31.8 & 627 & 38.4 & & \\
\hline 3. vgs. & 94 & 26.0 & 38 & 20.8 & & 289 & 22.4 & 264 & 16.2 & & \\
\hline Etnisitet & & & & & & & & & & & \\
\hline $\begin{array}{l}\text { Samisk } \\
\text { Ikke-samisk }\end{array}$ & & & & & & & & & & & $93.46^{* * *}$ \\
\hline Etnisk kontekst & & & & & $.57^{\mathrm{ns}}$ & & & & & $3.34^{\mathrm{ns}}$ & $29.09^{* * *}$ \\
\hline Samisk kjerneområde & 184 & 50.7 & 87 & 47.3 & & 19 & 1.5 & 40 & 2.4 & & \\
\hline Andre områder & 179 & 49.3 & 97 & 52.7 & & 1273 & 98.5 & 1612 & 97.6 & & \\
\hline Utdanningsretning & & & & & $2.58^{\mathrm{ns}}$ & & & & & $2.01^{\mathrm{ns}}$ & $3.11^{\mathrm{ns}}$ \\
\hline Studiespesialiserende & 187 & 51.5 & 107 & 58.8 & & 649 & 50.2 & 776 & 52.9 & & \\
\hline Yrkesfaglig & 176 & 48.5 & 75 & 41.2 & & 643 & 49.8 & 690 & 47.1 & & \\
\hline Bosituasjon under skolegang & & & & & $.90^{\mathrm{ns}}$ & & & & & $1.73^{\mathrm{ns}}$ & $5.28^{*}$ \\
\hline Hjemme & 203 & 56.1 & 111 & 60.3 & & 868 & 67.3 & 1031 & 69.7 & & \\
\hline Privat hybel/internat/annet & 159 & 43.9 & 73 & 39.7 & & 421 & 32.7 & 449 & 30.3 & & \\
\hline Indekser & Mean & SD & Mean & SD & $\mathbf{t}$ & Mean & SD & Mean & SD & $\mathbf{t}$ & $\mathbf{t}$ \\
\hline Atferd & 1.42 & .36 & 1.30 & .29 & $3.94^{* * * *}$ & 1.45 & .37 & 1.29 & .31 & $13.19^{* * *}$ & $13.70^{* * *}$ \\
\hline Selvbilde & 2.66 & .38 & 2.02 & .72 & $13.09^{* * *}$ & 2.57 & .37 & 2.06 & .71 & $22.82^{* * *}$ & $13.61^{* *}$ \\
\hline Forholdet til skole & 2.31 & .44 & 1.94 & .45 & $9.06^{* * *}$ & 2.20 & .44 & 1.92 & .46 & $17.05^{* * *}$ & $20.30^{* * *}$ \\
\hline Forholdet til familie/venner & 1.85 & .37 & 1.69 & .40 & $4.42^{* * * *}$ & 1.82 & .33 & 1.70 & .40 & $9.04^{* * *}$ & $10.30^{* * *}$ \\
\hline SCL-total & 1.64 & .52 & 1.75 & .66 & $-2.02^{*}$ & 1.61 & .48 & 1.81 & .70 & $-8.43^{* * *}$ & $8.71^{* * *}$ \\
\hline SCL-angst & 1.44 & .49 & 1.48 & .62 & $-.83^{\mathrm{ns}}$ & 1.41 & .46 & 1.53 & .66 & $-5.34^{* * *}$ & $-5.36^{* * *}$ \\
\hline SCL-depresjon & 1.82 & .61 & 1.98 & .77 & $-2.51^{*}$ & 1.78 & .57 & 2.04 & .80 & $-9.52^{* * *}$ & $-9.89^{* * *}$ \\
\hline
\end{tabular}

$* \mathrm{p}<.05 \quad * * \mathrm{p}<.01 \quad * * * \mathrm{p}<.001^{\#} \quad$ Lavere verdi $=$ mer problem

opprinnelige HSCL-10, har vi for angst- og depresjonssymptomer ikke benyttet en cut-off på 1,85 som er anbefalt for å beregne prevalensen av klinisk nivå av disse symptomene. Vi har benyttet 95-percentilen som en grenseverdi for «klinisk angst» og «klinisk depresjon» som tilsvarer gjennomsnittsverdien 3 for SCL-total, og 2,66 og 3,29 for hhv SCL-angst og SCLdepresjon. Verdien for SCL total er under verdien 4 som har vært benyttet av Ung i Norge-studien (6) og lik Ungdata-studiens cut-off på 3 (28).

\section{Sosiodemografiske variabler}

Måletidspunkt/år: 1994=1 og 2014=2.

Kjønn: Gutt=1 og jente=2.

Bosituasjon under skolegang: Hjemme=1 og Hybel/ internat/annet $=2$.

Etnisitet: Samisk bakgrunn ble kategorisert på bakgrunn av samisk språk i Ungdata, mens Ung i Nord både benyttet samisk språk og egendefinert samisk etnisitet. Mange samiske ungdommer, foreldre og besteforeldre har pga. fornorskningen ikke samisk språkkompetanse, men identifiserer seg likevel som samer $(26,38)$. Disse ble ikke fanget opp av Ungdatas definisjon. For å få sammenlignbare grupper, ble definisjonen i Ungdata benyttet for Ung i Nord. Etnisitet er definert som
Samisk $=1$ og Ikke-samisk $=2$.

Etnisk kontekst: De videregående skolene i de samiske kjerneområdene Kautokeino og Karasjok, ble kategorisert som Samisk kontekst $=1$ og resten som Annen kontekst $=2$. I det samiske kjerneområdet er majoriteten av befolkingen samiskspråklige og den strukturelle og kulturelle støtten til samisk identitet sterk i motsetning til andre kommuner. Ved de videregående skolene i Karasjok og Kautokeino foregår i hovedsak undervisningen på samisk samt at de også inkluderer fag som er særegen for samisk kultur slik som reindriftsfag og duoddji (samisk husflid).

Klassetrinn: Videregående trinn I/Grunnkurs (1994) = Vg1, Videregående trinn II/Videregående kurs I $(1994)=$ Vg2. Videregående trinn III/ Videregående kurs II (1994) = Vg3. Svaralternativene er: Vg1=1, $\mathrm{Vg} 2=2$ og $\mathrm{Vg} 3=3$.

Utdanningsretning: Studieforberedende utdanningsprogram/allmennfag (1994) $=1$ og Yrkesfaglig utdanningsprogram/yrkesfag $(1994)=2$.

\section{Psykososiale forhold}

For samtlige psykososiale indekser ble gjennomsnittsverdien regnet ut ved å summere verdiene for alle spørsmålene dividert med antall spørsmål. 
Tabell 2. Spørsmål inkludert i ulike indekser/skalaer i Ung i Nord og Ungdata: SCL-angst, SCL-depresjon og SCL-total, Forholdet til skolen, Forholdet til venner og familie, Atferdsproblemer og Selvfølelse.

\begin{tabular}{|c|c|}
\hline Spørsmål & Svaralternativer \\
\hline \multicolumn{2}{|l|}{ Har du i løpet av den siste uka vart plaget av noe av dette: } \\
\hline \multicolumn{2}{|l|}{ SCL-angst: } \\
\hline - Plutselig redd uten grunn & 1- Ikke plaget i det hele tatt \\
\hline - Stadig redd eller engstelig & 2- Litt plaget \\
\hline - Matthet eller svimmelhet & 3- Ganske mye plaget \\
\hline - Nervøsitet, indre uro & 4- Veldig mye plaget \\
\hline \multicolumn{2}{|l|}{ - Lett for å gråte } \\
\hline - Lett for å klandre seg selv & \\
\hline \multicolumn{2}{|l|}{ SCL- depresjon: } \\
\hline \\
\hline \multicolumn{2}{|l|}{ - Hatt søvnproblemer } \\
\hline \multicolumn{2}{|l|}{$\begin{array}{l}\text { - Følt deg ulykkelig, trist eller deprimert } \\
\text { - Følt håpløshet med tanke på framtida }\end{array}$} \\
\hline - Følt håpløshet med tanke på framtida & \\
\hline \multicolumn{2}{|l|}{ - Følt deg stiv eller anspent } \\
\hline \multicolumn{2}{|l|}{ - Bekymret deg for mye om ting } \\
\hline \multicolumn{2}{|l|}{ Forholdet til skole } \\
\hline \multirow{4}{*}{$\begin{array}{l}\text { Hvor lang tid bruker du gjennomsnittlig per dag på lekser og annet } \\
\text { skolearbeid (utenom skoletida)? }\end{array}$} & 1- Gjør aldri/nesten aldri lekser \\
\hline & 2- Mindre enn en halvtime \\
\hline & $3-1 / 2$ til 3 timer \\
\hline & 4- Mer enn 3 timer \\
\hline \multirow{4}{*}{$\begin{array}{l}\text { Har du gjort eller opplevd noe av dette det siste året? } \\
\text { - Hatt en voldsom krangel med en lærer } \\
\text { - Skulket skolen }\end{array}$} & 1- Ingen ganger \\
\hline & 2- 1 gang \\
\hline & 3- $2-5$ ganger \\
\hline & 4- 6 ganger eller mer \\
\hline \multirow{5}{*}{\multicolumn{2}{|c|}{$\begin{array}{l}\text { Er du enig eller uenig i følgende ut } \\
\text { - Jeg trives på skolen } \\
\text { - Jeg kjeder meg på skolen }{ }^{\#} \\
\text { - Jeg gruer meg ofte til å gå på s } \\
\text { Forholdet til foreldre og venner }\end{array}$}} \\
\hline & \\
\hline & \\
\hline & \\
\hline & \\
\hline \multirow{4}{*}{$\begin{array}{l}\text { - Foreldrene mine pleier å vite hvor jeg er, og hvem jeg er sammen } \\
\text { med i fritida } \\
\text { - Foreldrene mine kjenner de fleste av vennene jeg er sammen med i } \\
\text { fritida }\end{array}$} & 1- Passer svært godt/Stemmer helt/godt \\
\hline & 2- Passer ganske godt/Stemmer ganske \\
\hline & godt/omtrent \\
\hline & $\begin{array}{l}\text { 3- Passer ganske dårlig/svært dårlig/Stemmer } \\
\text { ikke særlig godt/Stemmer ikke i det hele tatt }\end{array}$ \\
\hline \multirow{3}{*}{$\begin{array}{l}\text { - Har du minst en venn som du kan stole fullstendig på og kan betro } \\
\text { deg til om alt mulig? (Ung i Nord) } \\
\text { - Jeg har en nær venn som jeg kan dele hemmeligheter med (Ungdata). }\end{array}$} & 1- Ja, helt sikkert/ Stemmer svært godt \\
\hline & 2- Ja, det tror jeg/ Stemmer nokså godt \\
\hline & $\begin{array}{l}\text { 3- Det tror jeg ikke/Har ingen jeg ville kalle ven- } \\
\text { ner nå for tiden/ Stemmer nokså /svært dårlig }\end{array}$ \\
\hline \multicolumn{2}{|l|}{ Atferdsproblemer } \\
\hline - Stjålet penger eller ting fra en du kjenner? & 1- Ingen ganger \\
\hline - Lurt deg fra å betale kino, idrettsstevner, buss, tog e.1.? & 2- 1 gang \\
\hline - Vært borte en hel natt uten at foreldrene dine visste hvor du var? & $3-2-5$ ganger \\
\hline - Vært i kontakt med politiet på grunn av noe galt du har gjort & 4- 6 ganger eller mer \\
\hline \multicolumn{2}{|l|}{ - Vært i slåsskamp hvor du har brukt våpen (f.eks. kniv)? } \\
\hline \multicolumn{2}{|l|}{$\begin{array}{l}\text { - Med vilje ødelagt eller knust vindusruter, busseter, postkasser e.l. } \\
\text { (gjort hærverk)? }\end{array}$} \\
\hline \multicolumn{2}{|l|}{ - Brutt deg inn for å stjele noe? } \\
\hline \multicolumn{2}{|l|}{ - Drukket så mye at du tydelig har følt deg beruset? } \\
\hline - Brukt hasj/marihuana/cannabis? & \\
\hline - Brukt andre narkotiske stoffer? & \\
\hline Selvfølelse & \\
\hline - Jeg er svært fornøyd med hvordan jeg er & 1- Passer svært godt \\
\hline - Jeg er stort sett fornøyd med meg selv & 2- Passer ganske godt \\
\hline - Jeg liker meg selv slik jeg er & 3- Passer ganske dårlig \\
\hline - Jeg er ofte skuffet over meg selv ${ }^{\#}$ & 4- Passer svært dårlig \\
\hline - Jeg liker ikke den måten jeg lever livet mitt på ${ }^{\#}$ & \\
\hline
\end{tabular}




\section{Forholdet til skolen}

Dette ble målt med utsagn om hvor mye tid som ble benyttet til lekser og skolearbeid, krangel med lærer, skulking og trivsel på skolen (Tabell 1). Alle spørsmålene ble skåret på en skala fra 1-4.

Verdiene for de to siste spørsmålene ble snudd. Lavere skåre indikerer et mer positivt forhold til skolen (Tabell 1).

\section{Forholdet til foreldre og venner}

Forholdet til foreldre ble målt med to spørsmål fra Parental Bonding Index (39), mens spørsmålene/utsagnene for forholdet til venner benyttet i Ung i Norge (40) er modellert etter Duane Buhrmeisters Friendship and Intimacy Inventory (41) og Wim Meuus skala for sosial støtte (42). Svaralternativene for forholdet til venner for de to undersøkelsene var noe forskjellig og ble bearbeidet til en tredelt skala som for de øvrige spørsmålene (Se Tabell 2). Lavere skåre indikerer et bedre forhold.

\section{Atferdsproblem}

Består av ti spørsmål om antisosial og opposisjonell atferd fra Ung i Norge (40) og delvis fra Olweus' skala for antisosial atferd og National Youth Longitudinal Study $(43,44)$. Spørsmålene dekker atferd som voldelig oppførsel, ulovlige handlinger, tyveri og bruk av rusmidler. Høyere skårer indikerer mer problem (Tabell 1).

\section{Selvfølelse}

Spørsmålene om selvfølelse er fra en revidert versjon av delskalaen «Global Self Worth» fra instrumentet «The Self-Perception Profile for Adolescents (SPPA)» (45). Skalaen har tidligere vært brukt i den longitudinelle undersøkelsen Ung i Norge (fra 1992 til 2005) samt $i$ alle tre rundene av tverrsnittsundersøkelsen Ung i Norge (1992, 2002 og 2010) (45). Lavere skåre indikerer en bedre selvfølelse (Tabell 1).

\section{Statistiske analyser}

For å sammenligne fordelingen av de sosiodemografiske forklaringsvariablene og prevalensen av angstog depresjonssymptomer mellom de to måletidspunktene, ble det benyttet krysstabeller og kji-kvadrattester. For å sammenligne angst- og depresjonssymptomer og de ulike psykososiale indeksene mellom måletidspunktene, ble det benyttet t-tester. Signifikansnivået ble satt til 0,05.

Forskjeller i forekomsten av moderat til alvorlige angst- og depresjonssymptomer målt med SCL-angst og SCL-depresjon ble undersøkt i hele utvalget med en logistisk regresjonsanalyse i 3 steg. Bivariate korrelasjonsanalyser ble utført for å undersøke for om de psykososiale forklaringsvariablene var korrelert innad. Ingen av korrelasjonene var høyere enn $\mathrm{r}=0,31$ og alle faktorene ble dermed inkludert i analysene. Effekten av år ble i steg 1 justert for de sosiodemografiske variablene (år, kjønn, etnisitet, etnisk kontekst, klassetrinn, utdanningsretning og bosituasjon under utdanning). I steg 2 ble effekten av de psykososiale faktorene ut- forsket justert for samtlige sosiodemografiske variablene. I steg 3 ble det undersøkt for interaksjoner mellom måletidspunkt (år) og forklaringsvariablene i hele utvalget. Bivariate analyser ble anvendt for å undersøke retningene for interaksjonene. For å undersøke for ulike mønstre av prediktorer for angst- og depresjonssymptomer hos samisk og ikke-samiske elever, ble det kjørt etnisk stratifiserte regresjonsanalyser i 2 steg. Det ble ikke inkludert et tredje steg med interaksjoner mellom år og forklaringsvariabler på grunn av det samiske utvalgets lave antall.

Statistikkprogrammet SPSS Statistics 25 ble benyttet for analysene.

\section{RESUltater}

Utvalgene av ungdommene som deltok i undersøkelsene i 1994 og 2014 er presentert i Tabell 1. Sammenlignet med 1994 var det totalt sett i 2014 færre elever på 3.klassetrinn og flere på 2.klassetrinn, færre samiske elever og færre elever fra det samiske kjerneområdet. Ved de videregående skolene i det samiske kjerneområdet var det begge årene flest samiske elever. I 1994 deltok flere jenter enn gutter i studien enn i 2014 og da på 2. og 3.klassetrinn. Valg av utdanningsretning viste ingen forskjell fra 1994 til 2014, men ved begge måletidspunktene var det flere gutter enn jenter som valgte yrkesfaglig utdanningsretning. Bosituasjonen under videregående skole viste ingen forskjell fra 1994 til 2014. De etnisk stratifiserte analysene av utvalgene viste enkelte forskjeller i forklaringsvariablenes effekt i det samiske og det ikke-samiske utvalget mellom 1994 og i 2014 (Tabell 1).

De psykososiale indeksene viste at elever i 2014 hadde et mer positivt forhold til skolen, foreldre og venner og mindre atferdsvansker enn i 1994, mens elevenes selvfølelse var svakere. I 1994 hadde jenter den beste selvfølelsen $(\mathrm{F}=5.74, \mathrm{p}<.001)$, mens det var omvendt i $2014(\mathrm{~F}=-10.67, \mathrm{p}<.001)$. Guttene rapporterte mer atferdsproblemer i 1994, men i 2014 var det ingen kjønnsforskjeller $(\mathrm{F}=6.24, \mathrm{p}<.001)$. Mens det $\mathrm{i}$ 1994 ikke var noen kjønnsforskjeller i forholdet til skole, foreldre og venner, endret dette seg i 2014 da gutter rapporterte et bedre forhold til skolen enn jenter $(\mathrm{F}=6.12, \mathrm{p}<.001)$ og jenter et bedre forhold til foreldre og venner enn gutter $(\mathrm{F}=6.37, \mathrm{p}<.001)$.

I 1994 rapporterte samisk ungdom et svakere selvbilde $(\mathrm{F}=4.08, \mathrm{p}<.001)$ og et mindre positivt forhold til skolen $(\mathrm{F}=3.07, \mathrm{p}<.001)$ enn ikke-samisk ungdom. Tjue år senere var disse etniske forskjellene ikke til stede.

Gjennomsnittsskårene for angst- og depresjonssymptomer i det totale utvalget var i 2014 høyere enn i 1994; $\mathrm{F}=-8.07, \mathrm{p}<.001$ for $\mathrm{SCL}$-angst, $\mathrm{F}=-5.36, \mathrm{p}<.001$ for SCL-depresjon (Figur 1). Det samme gjaldt for SCL-total $(\mathrm{F}=-5.36, \mathrm{p}<.001)$. I den samiske gruppen var det ikke en signifikant økning i angstsymptomer fra 1994 til 2014.

Prevalensen av klinisk angst og depresjon var i 2014 høyere enn i $1994\left(\mathrm{x}^{2}(2,3293)=95.3, \mathrm{p}<.001\right)$. 
Tabell 3. Logistisk regresjonsanalyse for SCL-angst, SCL-depresjon og måletidspunkt, sosiodemografiske og psykososiale forhold blant videregående skoleelever i Finnmark.

\begin{tabular}{|c|c|c|c|c|}
\hline & \multicolumn{2}{|c|}{ SCL-angst } & \multicolumn{2}{|c|}{ SCL-depresjon } \\
\hline & OR & $95 \% \mathrm{CI}$ & OR & $95 \% \mathrm{CI}$ \\
\hline \multicolumn{5}{|l|}{ Steg 1: } \\
\hline 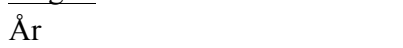 & $3.11^{* * *}$ & $2.10-4.60$ & $5.39^{* * *}$ & $3.45-8.41$ \\
\hline Kjønn & $7.58^{* * *}$ & $4.61-12.65$ & $4.58^{* * *}$ & $3.00-7.00$ \\
\hline 1. klassetrinn ${ }^{\S}$ & $2.08^{* *}$ & $1.22-3.53$ & $0.86^{\mathrm{ns}}$ & $0.53-1.38$ \\
\hline Etnisitet & $1.25^{\mathrm{ns}}$ & $0.66-2.37$ & $1.25^{\mathrm{ns}}$ & $0.66-2.37$ \\
\hline Etnisk kontekst & $0.83^{\mathrm{ns}}$ & $0.38-1.82$ & $1.11^{\mathrm{ns}}$ & $0.48-2.56$ \\
\hline Utdanningsretning & $1.39^{\mathrm{ns}}$ & $0.97-1.91$ & $1.41^{\mathrm{ns}}$ & $0.98-2.41$ \\
\hline Bosituasjon & $1.01^{\mathrm{ns}}$ & $0.70-1.48$ & $1.41^{\mathrm{ns}}$ & $0.99-2.02$ \\
\hline $\mathrm{R}^{2}$ & .045 & & .043 & \\
\hline \multicolumn{5}{|l|}{ Steg 2: } \\
\hline$\overline{\AA r}$ & $4.91^{* * *}$ & $3.18-7.59$ & $9.54^{* * *}$ & $5.82-15.63$ \\
\hline Kjønn & $6.35^{* * *}$ & $3.72-10.82$ & $3.19^{* * *}$ & $1.99-5.13$ \\
\hline 1. klassetrinn ${ }^{\S}$ & $2.43^{* *}$ & $1.35-4.39$ & $0.99^{\mathrm{ns}}$ & $0.57-1.73$ \\
\hline Bosituasjon & $0.97^{\mathrm{ns}}$ & $0.64-1.47$ & $1.56^{*}$ & $1.03-2.36$ \\
\hline Forhold til skole ${ }^{\#}$ & $3.90^{* * *}$ & $2.51-6.06$ & $4.93^{* * *}$ & $3.14-7.44$ \\
\hline Forhold til foreldre og venner ${ }^{\#}$ & $1.19^{\mathrm{ns}}$ & $0.71-2.00$ & $0.86^{\mathrm{ns}}$ & $0.51-1.47$ \\
\hline Atferdsvansker & $1.33^{\mathrm{ns}}$ & $0.74-2.40$ & $1.06^{\mathrm{ns}}$ & $0.57-1.97$ \\
\hline Selvfølelse ${ }^{\#}$ & $5.37^{* * *}$ & $3.78-7.64$ & $7.53 * * *$ & $5.24-10.82$ \\
\hline $\mathrm{R}^{2}$ & .11 & & .13 & \\
\hline
\end{tabular}

Mens 2.1\% av ungdommene i 1994 hadde klinisk angst- og depresjon, var det tilsvarende tallet for 2014 $8.3 \%$, altså en firedobling. Prevalensen økte fra $3.6 \%$ blant jenter i 1994 til $13.2 \%$ i $2014\left(\mathrm{x}^{2}(2,1611)=\right.$ 26.6, $\mathrm{p}<.001)$, mens den blant gutter økte fra $0.6 \% \mathrm{i}$ 1994 til $3.3 \%$ i $\left.2014\left(\mathrm{x}^{2}(2,1682)=95.4, \mathrm{p}<.001\right)\right)$. Økningen skjedde både blant samiske og ikke-samiske elever $(\mathrm{p}<.001$ for begge etniske grupper). Det var ingen etniske forskjeller $\mathrm{i}$ prevalensen ved de to måletidspunktene, men det var en tendens til en svakere økning fra 1994 til 2014 for samisk ungdom $\left(\mathrm{x}^{2}(2,523)=6.5, \mathrm{p}=.04\right)$ enn for ikke-samisk ungdom $\left(\mathrm{x}^{2}(2,2780)=87.9, \mathrm{p}<.001\right)$. Forskjellene mellom forekomsten av klinisk angst og depresjon i 1994 og 2014 forble signifikante når de var justert for kjønn, etnisitet, klassetrinn, utdanningsretning, bosituasjon og etnisk kontekst i steg 1 av analysene (Tabell 3).

Jenter og elever på første klassetrinn hadde høyest forekomst av klinisk angst. Det var en sterk tendens til høyere forekomst blant elever på yrkesfaglig utdanningsretning enn studieforberedende utdanningsretning. I likhet med klinisk angst var kjønn og utdanningsretning signifikante prediktorer for klinisk depresjon, mens bosituasjonen under skolegang også viste en sterk tendens til mer problemer blant borteboere. Det var ingen forskjeller mellom samiske og ikke-samiske elever eller elever i de samiske områdene versus andre områder verken for forekomsten av klinisk angst- eller depresjon.

Av de psykososiale faktorene inkludert i steg 2 i den logistiske regresjonsanalysen var elevenes forhold til skole og selvfølelse de sterkeste prediktorene for både kliniske angst og klinisk depresjon. Atferdsvansker og forholdet til foreldre og venner var ikke signifikante for noen av plagene (Tabell 3).

I steg 3 ble det kontrollert for interaksjoner mellom måletidspunkt (år) og alle forklaringsvariablene for både klinisk angst og klinisk depresjons. Ingen av interaksjonene var signifikante, men det var en nesten signifikant interaksjon mellom år og kjønn for kliniske depresjonssymptomer $(\mathrm{p}=.052)$. Bivariate analyser viste at forskjellen mellom 1994 og 2014 var større for jenter $\left(\mathrm{x}^{2}(1,1678)=50,25\right)$ enn for gutter $\left(\mathrm{x}^{2}(1,1608)\right.$ $=21.62)$.

De etnisk stratifiserte analysene viste som for hele utvalget at måletidspunkt, kjønn, forholdet til skole og selvfølelse var de sterkeste prediktorene for både klinisk angst og klinisk depresjon for både samiske og ikke- samiske elever. De ikke-samiske elevene på første klassetrinn hadde mer klinisk angst enn elever på tredje klassetrinn $\left(\mathrm{OR}=.66^{\mathrm{p}<.001,} \mathrm{CI95 \%}(.51-.86) \mathrm{og}\right.$ ikke-samiske borteboere mer klinisk depresjon enn hjemmeboere $\left(\mathrm{OR}=1.58^{\mathrm{p}=.046}\right.$, CI95\% (2.1.01-2.47)). I samme gruppe var et godt forhold til foreldre og venner beskyttende mot klinisk depresjon $(\mathrm{OR}=$ $.62^{\mathrm{p}=.09}$, CI95\% (.35-1.09)).

For de samiske elevene var et godt forhold til foreldre og venner relatert både til lavere forekomst av klinisk angst og depresjon; OR $=5.19^{\mathrm{p}=.026}, \mathrm{C} 195 \%$ $(1.22-22.05)$ og $\mathrm{OR}=15.12^{\mathrm{p}=.005}$, CI95\% (2.24-102.16) for hhv klinisk angst og klinisk depresjon. 


\section{DISKUSJON}

I 2014 hadde hver sjuende kvinnelige og hver ellevte mannlige elev i den videregående skolen i Finnmark moderat til alvorlige angst- og depresjonssymptomer noe som var en firedobling sammenlignet med 1994. Hovedfunnene i denne undersøkelsen viser en sterk sammenheng mellom elevenes angst- og depresjonssymptomer og kjønn, forholdet til skole og selvfølelse. Disse sammenhengene endret seg ikke fra 1994 til 2014 og gjaldt for både samiske og ikke-samiske elever. Verken etnisitet, etnisk kontekst eller atferdsvansker hadde en signifikant betydning, men ikkesamiske elevers angst- og depresjonssymptomer var i større grad påvirket av sosiodemografiske og psykososiale forhold enn samiske elevers.

Økningen i forekomsten av angst- og depresjonssymptomer i 1994 sammenlignet med 2014 samsvarer både med nasjonale og internasjonale spørreskjemastudier. Både Ung i Norge og Ungdataundersøkelsene viste en klar økning av angst- og depresjonssymptomer blant jenter, mens det var et mer varierende bilde for gutter med en økning fra 90-tallet og fram til $2010 \mathrm{og}$ deretter en svak nedgang $(6,13,46)$. Resultatene fra vår studie viser derimot en klar økning for begge kjønn, men mest for jenter. I andre land som det er naturlig å sammenligne seg med som Island og Nederland har man også funnet en økning $\mathrm{i}$ angst- og depresjonssymptomer for begge kjønn fra 1980-tallet til 2000tallet (47).

Det finnes svært få undersøkelser av angst- og depresjonssymptomer for ungdom i Finnmark. Ungdataundersøkelsen fra 2014 som våre data er hentet fra og som omfatter alle fylkene $i$ landet har vist at elever i Finnmark sammen med elever i Nordland har den høyeste forekomsten av angst- og depresjonssymptomer på 13\% (28). I vår undersøkelse har vi hatt strengere kriterier for definisjon av moderate til alvorlige depresjonssymptomer. Forekomsten i denne studien er derfor lavere enn eksisterende tall for Ungdata. Det samme gjelder data fra Ungdomsundersøkelsen hvor ungdomsskoleelever i Nord-Norge hadde en prevalens av angst- og depresjonssymptomer på ca. $20 \%$ og lik forekomst $\mathrm{i}$ alle de tre nordligste fylkene ved bruk av den anbefalte grenseverdi på 1,85 (14).

Noen studier har i likhet med våre funn vist at jenter er mer utsatt for en økning i depressive symptomer over tid enn gutter $(2,47)$, mens tidligere studier ikke har vist noen kjønnsforskjell $(48,49)$. Det er mulig at jenter eksponeres nå som tidligere av flere risikofaktorer for angst og depresjon enn gutter, som utviklingsmessige utfordringer i puberteten i forhold til kjønnsroller, forholdet til egen kropp og vekt, forventninger (50) og at dette er blitt sterkere de siste årene.

Vi fant en beskyttende effekt av en god selvfølelse på angst- og depresjonssymptomer som også er vist $\mathrm{i}$ andre studier (51-53). Blant jenter kan en svekket selvfølelse ha vært en medvirkende faktor til en økning i angst- og depresjonssymptomene fra 1994 til 2014.
Guttene derimot hadde en positiv utvikling av selvfølelsen i samme periode hvor det samtidig var en økning av angst- og depresjonssymptomer om enn ikke like sterk som for jentene. I vår studie var det kun to måletidspunkt. Ved hyppigere målinger ville det vært mulig å se nærmere på eventuelle endringer i sammenhengen mellom selvfølelse og angst- og depresjonssymptomer over tid hos jenter og gutter.

I denne studien var et godt forhold til skolen en gjennomgående beskyttende faktor for angst- og depresjonssymptomer og bekrefter tidligere studier av depresjonssymptomer hos ungdom (54). Gutters forhold til skolen endret seg fra 1994 til 2014 til det bedre og kan i likhet med selvfølelse ha bidratt til en lavere økning $\mathrm{i}$ forekomsten av angst- og depresjonssymptomer enn hos jenter.

Jenter på yrkesfaglig studieretning slet mer med angst enn jenter på studiespesialiserende utdanningsretning. Det er mulig at jenter med psykiske problem i større grad velger yrkesfaglige utdanningsretninger. Dette kan også være knyttet til at de ikke har en sterk nok selvfølelse for å ta fatt på en studiespesialiserende utdanningsretning.

I vår studie var sosial støtte beskyttende for depresjonssymptomer, men ikke for angstsymptomer. Sosial støtte og kontakt er vist å ha en sammenheng med økning i angst- og depresjonssymptomer over tid (55). Våre funn av den beskyttende effekten av et godt forhold til foreldre og venner og å bo hjemme under skolegang samsvarer med disse tidligere funn. Dette var spesielt viktig for ikke-samiske elever. I det samiske samfunnet er storfamilien eller den utvidede familien med onkler, tanter, besteforeldre og gudforeldre viktig og deltar i oppdragelsen av barn (56). Det er mulig at samiske elever i større grad opplever støtte fra storfamilien som en erstatning for mindre støtte fra foreldre og venner og dermed ikke er så sårbare for depresjonssymptomer som ikke-samiske medelever.

Det var ingen statistiske forskjeller i forekomsten av angst- og depresjonssymptomer mellom samiske og ikke-samiske elever på noe måletidspunkt, og små forskjeller i prediktorer. Imidlertid så vi en tendens til at angst- og depresjonsproblemer viste en lavere økning for samisk ungdom enn ikke-samisk. I tidligere undersøkelser av angst- eller depresjonssymptomer har det vært små eller ingen forskjeller mellom samisk og ikke-samisk ungdom i forekomsten av problemer $(14,29,30)$. Imidlertid har disse studiene også inkludert samisk ungdom uten språktilhørighet hos seg selv eller foreldre i motsetning til utvalget fra 2014 i denne studien. Det kan stilles spørsmål om en inklusjon av samiske elever uten språktilhørighet ville ha endret estimatet av angst- og depresjonssymptomer for samiske elever i 2014. Samisk språkkompetanse hos samisk jenter i ungdomsskolen er tidligere funnet å ha en beskyttende effekt på angst- og depresjonssymptomer (23). Det kan derfor være en mulighet for at en eksklusjon av samiske elever uten språktilhørighet kan 
ha ført til en skjevhet i utvalget som kan ha redusert estimatet av forekomsten av angst- og depresjonssymptomer i 2014. Dersom flere elever med problemer ville ha vært inkludert i 2014, ville det også ha vært en større forskjell mellom 1994 og 2014. På den annen side er det færre antall elever fra det samisk kjerneområdet som deltar i undersøkelsen i 2014 enn i 1994, noe som representerer både en geografisk og etnisk skjevfordeling i utvalget. Majoriteten av befolkningen i det samiske kjerneområdet er samer og samisktalende (ca. 80-90\%). Samisk ungdom fra dette området er tidligere funnet å ha færre emosjonelle problem enn for ikke-samisk samisk ungdom og samisk ungdom fra andre kontekster hvor samer er i mindretall (25).

\section{Styrker og svakheter ved undersokelsene}

Ung i Nord og Ungdata har begge gode responsrater, store og representative utvalg av både ikke-samisk og samisk ungdom fra alle videregående skoler i Finnmark med ungdom. Undersøkelsene har også benyttet de samme måleinstrumentene for angst- og depresjonssymptomer på de to måletidspunktene. Funnene kan derfor sies å gi et representativt bilde av psykisk helse hos ungdom i Finnmark på to måletidspunkt og kanskje spesielt i 1994 hvor svarprosenten var høyest.

En annen styrke er at undersøkelsene inkluderte spørsmål rundt etnisitet noe som gjorde det mulig å sammenligne samisk og ikke-samisk ungdom. Imidlertid er det en svakhet med studien at Ungdata har benyttet en snevrere definisjon av samisk tilhørighet enn Ung i Nord. Dette medfører at det ikke-samiske utvalget inkluderer samisk ungdom med samisk identitet, men uten språktilhørighet.

Undersøkelsene har ikke hatt eksakt samme formuleringer på alle forklaringsvariablene, og heller ikke nøyaktig like svaralternativer. Disse har blitt tilpasset og rekodet for å kunne slå sammen datafilene og sammenligne resultater. Resultatene er derfor mindre presise enn de ville ha vært dersom Ung i Nord og Ungdata hadde benyttet eksakt samme spørsmålene og verdier.

En annen begrensning i denne studien er manglende forklaringsvariabler som er funnet å påvirke forekomsten av angst- og depresjonsproblemer slik som etnisk diskriminering.

Denne studien er basert på kartlegging av angst- og depresjonssymptomer på kun to måletidspunkt. Det ville styrket studien med jevnlige målinger med spørreskjema som også inkluderer funksjonsmål i tillegg til symptommål for å kunne måle tidstrender i utviklingen av angst- og depresjonssymptomer og undersøke sammenhengen mellom symptomer og funksjonsnivå over tid. En mulighet er at ungdommenes rapporteringsstil er blitt mer åpen i løpet av de siste årene noe som øker symptomrapporteringen, men ikke nødvendigvis medfører funksjonsfall.

\section{KONKLUSJON}

Forekomsten av angst- og depresjonssymptomer hos eldre ungdom i Finnmark er fire ganger høyere i 2014 enn i 1994. Å være gutt, å ha god selvtillit og et godt forhold til skole virker beskyttende både mot angst og depresjonsplager. Samisk tilhørighet representerer ingen risiko. Mer forskning med utvidede mål og hyppigere kartlegging er viktig for å studere tidstrender og funksjonsnivå og for å utforme gode forebyggende tiltak og et tilpasset behandlingstilbud for både samisk og ikke-samisk ungdom.

\section{REFERANSER}

1. Maughan B, Collishaw S, Meltzer H, Goodman R. Recent trends in UK child and adolescent mental health. Soc Psychiatry Psychiatr Epidemiol 2008;43(4):305-10.

2. Collishaw S, Maughan B, Natarajan L, Pickles A. Trends in adolescent emotional problems in England: a comparison of two national cohorts twenty years apart. J Child Psychol Psychiatry 2010;51(8):885-94.

3. Konowałek $€$, Wolanczyk T. Changes in emotional and behavioral problems between 2000 and 2011 among 16-year-old Polish children: A cross-sectional study. Child Psychiatry Hum Dev 2018;49(5):757-65.

4. Collishaw S. Annual research review: Secular trends in child and adolescent mental health. J Child Psychol Psychiatry 2015;56(3):370-93.

5. Costello EJ, Egger H, Angold A. 10-year research update review: the epidemiology of child and adolescent psychiatric disorders: I. Methods and public health burden. J Am Acad Child Adolesc Psychiatry 2005; 44(10):972-86.

6. von Soest T, Wichstrøm L. Secular trends in depressive symptoms among Norwegian adolescents from 1992 to 2010. J Abnorm Child Psychol 2014;42(3):403-15.

7. Costello EJ, Egger HL, Angold A. The developmental epidemiology of anxiety disorders: phenomenology, prevalence, and comorbidity. Child Adolesc Psychiatr Clin N Am 2005;14(4):631-48, vii.

8. Copeland W, Shanahan L, Costello EJ, Angold A. Cumulative prevalence of psychiatric disorders by young adulthood: a prospective cohort analysis from the Great Smoky Mountains Study. J Am Acad Child Adolesc Psychiatry 2011;50(3):252-61.

9. Jane Costello E, Erkanli A, Angold A. Is there an epidemic of child or adolescent depression? J Child Psychol Psychiatry 2006;47(12):1263-71. 
10. Puura K, Almqvist F, Tamminen T, Piha J, Kumpulainen K, Räsänen E, et al. Children with symptoms of depression - what do the adults see? J Child Psychol Psychiatry 1998;39(4):577-85.

11. Egger HL, Angold A. Common emotional and behavioral disorders in preschool children: presentation, nosology, and epidemiology. J Child Psychol Psychiatry 2006;47(3-4):313-37.

12. Puura K, Almqvist F, Tamminen T, Piha J, Kumpulainen K, Räsänen E, et al. Children with symptoms of depression - what do the adults see? J Child Psychol Psychiatry 1998;39(4):577-85.

13. Bakken A. Ungdata 2017. Nasjonale resultater [Internet]. Oslo: NOVA og Høgskolen i Oslo og Akershus; 2017 Aug [cited 2017 Aug 1] p. 117. Available from: http://kriminalitetsforebygging.no/wp-content/uploads/ 2017/08/Ungdata-rapport-2017-4-august-2017-web-utg-med-omslag.pdf.

14. Eckhoff C, Kvernmo S. Musculoskeletal pain in Arctic indigenous and non-indigenous adolescents, prevalence and associations with psychosocial factors: a population-based study. BMC Public Health 2014;14:617.

15. Heyerdahl S, Kvernmo S, Wichstrøm L. Self-reported behavioural/emotional problems in Norwegian adolescents from multiethnic areas. Eur Child Adolesc Psychiatry 2004;13(2):64-72.

16. Sund AM, Larsson B, Wichstrøm L. Prevalence and characteristics of depressive disorders in early adolescents in central Norway. Child Adolesc Psychiatry Ment Health 2011;5:28.

17. Kovacs M, Devlin B. Internalizing disorders in childhood. J Child Psychol Psychiatry 1998;39(1):47-63.

18. Mathiesen KS, Kjeldsen A, Skipstein A, Karevold E. Trivsel og oppvekst-barndom og ungdomstid. Oslo: Folkehelseinstituttet; 2007. Report No. 2007:5.

19. Skrove M, Romundstad P, Indredavik MS. Resilience, lifestyle and symptoms of anxiety and depression in adolescence: the Young-HUNT study. Soc Psychiatry Psychiatr Epidemiol 2013;48(3):407-16.

20. Moksnes UK, Espnes GA. Self-esteem and emotional health in adolescents - gender and age as potential moderators. Scand J Psychol 2012;53(6):483-9.

21. von Soest T, Wichstrøm L, Kvalem IL. The development of global and domain-specific self-esteem from age 13 to 31. J Pers Soc Psychol 2016;110(4):592-608.

22. Bals M, Turi AL, Vittersø J, Skre I, Kvernmo S. Self-reported internalization symptoms and family factors in indigenous Sami and non-Sami adolescents in North Norway. J Adolesc 2011;34(4):759-66.

23. Bals M, Turi AL, Skre I, Kvernmo S. The relationship between internalizing and externalizing symptoms and cultural resilience factors in Indigenous Sami youth from Arctic Norway. Int J Circumpolar Health 2011; 70(1):37-45.

24. Bals M, Turi AL, Skre I, Kvernmo S. Internalization symptoms, perceived discrimination, and ethnic identity in indigenous Sami and non-Sami youth in Arctic Norway. Ethn Health 2010;15(2):165-79.

25. Kvernmo S, Heyerdahl S. Influence of ethnic factors on behavior problems in indigenous Sami and majority Norwegian adolescents. J Am Acad Child Adolesc Psychiatry 1998;37(7):743-51.

26. Kvernmo S, Heyerdahl S. Acculturation strategies and ethnic identity as predictors of behavior problems in arctic minority adolescents. J Am Acad Child Adolesc Psychiatry 2003;42(1):57-65.

27. Mojtabai R, Olfson M, Han B. National trends in the prevalence and treatment of depression in adolescents and young adults. Pediatrics 2016;138(6):e20161878.

28. Bakken A. Ungdata. Nasjonale resultater 2014. Oslo: Norsk institutt for oppvekst og aldring (NOVA); 2015 Jun. Report No. 7/15.

29. Heyerdahl S, Kvernmo S, Wichstrøm L. Self-reported behavioural/emotional problems in Norwegian adolescents from multiethnic areas. Eur Child Adolesc Psychiatry 2004;13(2):64-72.

30. Kvernmo S, Heyerdahl S. Ethnic identity and acculturation attitudes among indigenous Norwegian Sami and ethnocultural Kven adolescents. J Adolesc Res 2004;19(5):512-532.

31. Derogatis LR, Lipman RS, Rickels K, Uhlenhuth EH, Covi L. The Hopkins Symptom Checklist (HSCL). A measure of primary symptom dimensions. Mod Probl Pharmacopsychiatry 1974;7(0):79-110.

32. Kandel DB, Davies M. Epidemiology of depressive mood in adolescents: an empirical study. Arch Gen Psychiatry 1982;39(10):1205-12.

33. Sørlie T, Hansen KL, Friborg O. Do Norwegian Sami and non-indigenous individuals understand questions about mental health similarly? A SAMINOR 2 study. Int J Circumpolar Health 2018;77(1):1481325.

34. Sirpal MK, Haugen W, Sparle K, Haavet OR. Validation study of HSCL-10, HSCL-6, WHO-5 and 3-key questions in 14-16 year ethnic minority adolescents. BMC Fam Pract 2016;17:7.

35. von Soest T. Tidstrender for depressive symptomer blant norske ungdommer fra 1992 til 2010. Tidsskrift for Ungdomsforskning 2012;12(2):3-20.

36. Haavet OR, Sirpal MK, Haugen W, Christensen KS. Diagnosis of depressed young people in primary health care - a validation of HSCL-10. Fam Pract 2011;28(2):233-7.

37. Strand BH, Dalgard OS, Tambs K, Rognerud M. Measuring the mental health status of the Norwegian population: a comparison of the instruments SCL-25, SCL-10, SCL-5 and MHI-5 (SF-36). Nord J Psychiatry $2003 ; 57(2): 113-8$.

38. Kvernmo S, Heyerdahl S. Ethnic identity in aboriginal Sami adolescents: the impact of the family and the 
ethnic community context. J Adolesc 1996;19(5):453-63.

39. Parker G, Tupling H, Brown LB. A parental bonding instrument. Br J Med Psychol 1979;52(1):1-10.

40. Pedersen W, Mastekaasa A, Wichstrøm L. Conduct problems and early cannabis initiation: a longitudinal study of gender differences. Addiction 2001;96(3):415-31.

41. Buhrmester D. Intimacy of friendship, interpersonal competence, and adjustment during preadolescence and adolescence. Child Dev 1990;61(4):1101-11.

42. Meeus W. Parental and peer support in adolescence. In: Hurrelman K, Engel U, editors. Prevention and intervention in childhood and adolescence, 5. The social world of adolescents: International perspectives. Oxford, England: Walter De Gruyter, 1989: 167-83.

43. Olweus D. Bully/victim problems among schoolchildren: Basic facts and effects of a school based intervention program. In: Pepler DJ, Rubin KH, editors. The development and treatment of childhood aggression. Hillsdale, NJ, US: Lawrence Erlbaum Associates, 1991: 411-48.

44. Windle M. A longitudinal study of antisocial behaviors in early adolescence as predictors of late adolescent substance use: gender and ethnic group differences. J Abnorm Psychol 1990;99(1):86-91.

45. Wichstrøm L. Harter's self-perception profile for adolescents: reliability, validity, and evaluation of the question format. J Pers Assess 1995;65(1):100-16.

46. Wichstrøm L. Depresjon og suicidalitet. I: Ung i Norge psykososiale utfordringer, Kvalem og Wichstrøm, red. Oslo: Cappelen akademiske forlag, 2007.

47. Sigfusdottir ID, Asgeirsdottir BB, Sigurdsson JF, Gudjonsson GH. Trends in depressive symptoms, anxiety symptoms and visits to healthcare specialists: a national study among Icelandic adolescents. Scand J Public Health 2008 Jun;36(4):361-8.

48. Collishaw S, Maughan B, Goodman R, Pickles A. Time trends in adolescent mental health. J Child Psychol Psychiat 2004;45(8):1350-62.

49. Tick NT, van der Ende J, Verhulst FC. Twenty-year trends in emotional and behavioral problems in Dutch children in a changing society. Acta Psychiatr Scand 2007;116(6):473-82.

50. Wichstrøm L. The emergence of gender difference in depressed mood during adolescence: the role of intensified gender socialization. Dev Psychol 1999;35(1):232-45.

51. Martinsen KD, Neumer S-P, Holen S, Waaktaar T, Sund AM, Kendall PC. Self-reported quality of life and self-esteem in sad and anxious school children. BMC Psychol 2016;4(1):45.

52. Orth U, Robins RW, Roberts BW. Low self-esteem prospectively predicts depression in adolescence and young adulthood. J Pers Soc Psychol 2008;95(3):695-708.

53. Moksnes UK, Espnes GA. Self-esteem and emotional health in adolescents - gender and age as potential moderators. Scand J Psychol 2012;53(6):483-9.

54. Smokowski PR, Guo S, Evans CBR, Wu Q, et al. Risk and protective factors across multiple microsystems associated with internalizing symptoms and aggressive behavior in rural adolescents: Modeling longitudinal trajectories from the Rural Adaptation Project. Am J Orthopsychiatry 2017;87(1)94-108.

55. Van Droogenbroeck F, Spruyt B, Keppens G. Gender differences in mental health problems among adolescents and the role of social support: results from the Belgian health interview surveys 2008 and 2013. BMC Psychiatry 2018 Jan 10;18(1):6.

56. Balto A. Samisk barneoppdragelse i endring. Oslo: Ad Notam Gyldendal, 1997. 